\title{
More on broadening the lines of
}

\section{communication}

\author{
By Margaret R. Dittemore
}

Assistant Bibliographer for the Social Sciences

Tulane University

\section{Getting involved with the scholarly community.}

atricia Buck Dominguez's concern with

"Broadening the Lines of Communication" (C\&RL News, May 1990) among ALA, librarians, faculty, and scholarly organizations is timely and well-stated. ${ }^{1}$ The current discussion in the literature and at meetings on this topic is a very important one and may yield substantive results. Towards that end, I would like to comment on several of the steps Dominguez recommends our profession take.

Dominguez points to the importance of individuals in this effort when advocating that librarians become "more active in nonlibrary associations, in order to present the library's point of view on various issues." Such activity would certainly contribute towards broadening communication and would not be that difficult for ALA and its members to accomplish. In the past several decades, an increasing number of individuals have entered librarianship with prior experience in other fields. Among these are librarians who have worked in publishing or in the book trade and those who have academic preparation in other subject areas. With their prior knowledge of kindred groups, these individuals could contribute substantially towards integrating our profession into the broader publishing and educational community and increasing our visibility there.

I focus my comments here on one subset of this

'Patricia Buck Dominguez, “ALA, Librarians, Faculty, and Scholarly Organizations," $C \& R L$ News 51 (May 1990): 396-97. group-those with second graduate degrees in other subject disciplines. They are especially wellequipped to assist in this effort within the scholarly community itself. Their involvement in other scholarly organizations and publication in the journals of these organizations would greatly increase communication among us and promote a better understanding of who we are. There is much that we write in our own journals-surveys of the subject literature, histories of the bibliography of a field, discussions of changing modes of scholarly communication, etc.-that with some modification would be appropriate for other subject or higher education journals as well. In addition, there is a real need (as evidenced by Dominguez's MLA experience) for discussion groups or sections voicing library concerns within those scholarly organizations. These are only a few examples. There are numerous other opportunities for profitable exchange.

Of course, there are some librarians who are already active participants in other organizations or exchanges. Their participation mainly requires personal time, effort, and resources. Surveys show that much research and writing in librarianship is done this way. However, there are professional rewards for the latter that do not usually accompany the former. Membership and participation in other associations is as costly as ALA, and holding two such memberships (i.e., ALA and another subject area) can be quite burdensome. If the profession truly seeks to integrate itself into larger kindred groups, then it must provide more substan- 
tive professional and institutional encouragement of and support for these kinds of activities.

True integration of librarians into larger communities, both of their own college or university and of other disciplines, can really only take place at the grass roots level. The large number of librarians with prior experience in other areas presents our profession with the unique opportunity to accomplish this goal fairly readily. If this is what we want, why aren't we taking advantage of it?

A second step recommended by Dominguez is that ALA "should identify speakers and develop programs on library-related matters for presentation at national and regional scholarly or publishing conferences." ALA has many such opportunities through its own Annual Conference programming every year. In spite of the lack of funding available to participate in these programs, they attract an impressive array of speakers on a number of important and timely topics. Many of these would be appropriate candidates as "repeat" sessions at the meetings of other professional associations as well. Pick up your program for the 1990 Annual Conference and the crossovers will jump out at you.

At least one attempt to "repeat" an ALA session has already been made. Recently, ACRL's Anthropology and Sociology Section (ANSS) investigated submitting its 1989 program, "Access to Anthropological Fieldnotes: Preservation, Collection and Ethical Issues," to the 1990 American Anthropological Association (AAA) Annual Meeting. The program was well received by librarians and the topic has some currency in the field of anthropology. The program chair, Bonnie Wright, felt the program should be promoted. The speakers all agreed to present their material again, and two additional senior anthropologists accepted invitations to participate. However, further research revealed that all participants in sessions had to be registered and that only a selected number could participate without AAA membership. As several of the speakers were not AAA members and would have been attending the conference at their own expense only to participate in this session, they felt they could not accept the extra financial burden of membership dues. As a result, the program will not be repeated, a loss to both AAA and ALA.

ALA and its members would also greatly benefit from the publication of many ALA sessions. Those that are interdisciplinary in nature would find a broader audience, not only among librarians but in other subject disciplines as well. The possibility of publication would also enhance invitations to potential speakers by program planners in coming years. "Repeat" sessions and publications would contribute substantially both to our integration into the larger scholarly community and to our visibility there. We are truly shortchanging ourselves by not promoting further some of the quality programming that is developed every year. However, substantive support from the library profession is required if such efforts are to succeed.

William Moffett's title for his guest editorial in the November issue of College and Research Libraries, "Talking To Ourselves," was aptly chosen. ${ }^{2}$ As a profession, we indeed do a lot of that. The problem is not unique, however. It is one that other professional associations are struggling with as well. In our case, there are certainly a number of relatively easy first steps to take if we as individuals, as institutions, and as a profession are willing to do so.

${ }^{2}$ William A. Moffett, "Guest Editorial: Talking to Ourselves," College and Research Libraries 50 (November 1989): 609-10.

\section{Abstracts needed for practical sessions}

The 19th National LOEX Library Instruction Conference to be held in Ypsilanti, Michigan, May 10-11, 1991, will feature 30-minute practical instruction sessions and poster sessions. Anyone interested in presenting a session may submit an abstract. The sessions should deal with working with faculty in the new electronic library environment, although not necessarily with computers or any technology at all; human to human interaction is entirely acceptable. Some suggestions are listed below, although other topics will be considered:

- designing curriculum with faculty;

- teaching faculty or graduate students to use research facilities;

- designing and implementing CAI with or for faculty;
- marketing library instruction to faculty;

- any cooperative venture with faculty or special outreach;

- working with faculty or administrators to reach special groups such as minorities, part-time students, returning adult students, extended campus students, etc.;

- evaluating library instruction with faculty.

Teaching faculty as well as librarians are invited to participate.

Submit a one-page abstract with proposed title, audiovisual requirements, name, address, and phone number by January 10, 1991, to: Director, LOEX Clearinghouse, Eastern Michigan University Library, Ypsilanti, MI 48197; (313) 487-0168. 